\title{
33
}

\section{Drinking Water Quality and Techniques for Recharging an Urban Water System \\ - for the industrial city of Baroda, India}

B R Pandit and Hitesh Solanki

The major part of Gujarat in Western India is arid to semi arid with an average annual rainfall of about 500-700 mm. Baroda is an important industrial center of India situated in Gujarat. The city has experienced a heavy influx of population with a rise in industrialization. This has resulted in scarcity of water in the city area. Water pollution has become a major issue in the development of surface and groundwater resources for the protection of the fragile ecosystem. In the present chapter the quality of drinking water, and techniques for water harvesting, are discussed.

The main sources of pollution are the industrial effluents from industries producing, for example, fertilizers, petrochemicals, pesticides, pharmaceuticals, corrosive materials, organic wastes etc. The domestic sector also produces solid and liquid wastes. In all, 26 physico-chemical parameters and a few heavy metals were analyzed season-wise for a period of $2 \mathrm{y}$ in the five ponds of Baroda city, to study the impact of urbanization and industrialization on the quality of the water. Parameters like $\mathrm{pH}$, turbidity, total hardness, sulfates, chlorides, fluorides, TDS, BOD, COD, DO etc were estimated and are discussed in the chapter.

All the studied parameters were in higher concentrations than the control. This is because of biotic activities in the pond, such as the decomposition of

Pandit, B.R. and H. Solanki. 2004. "Drinking Water Quality and Techniques for Recharging an Urban Water System - for the industrial city of Baroda, India." Journal of Water Management Modeling R220-33. doi: 10.14796/JWMM.R220-33.

(C) CHI 2004 www.chijournal.org ISSN: 2292-6062 (Formerly in Innovative Modeling of

Urban Water Systems. ISBN: 0-9683681-9-0) 
dead organic matter. During the study arsenic, lead and mercury were not observed, whereas cadmium and chromium were recorded a little higher than the permissible limit in two ponds only. This may be due to some small-scale industries in the area. The correlation coefficient between the physicochemical characters of the surface waters was calculated. The water is not suitable for direct consumption and a slight abnormality in the quality of water was indicated.

The surface and ground water systems are inextricably linked. In most cases, this surface water system recharges the underlying aquifer. Various techniques to harvest water include tube well recharging, percolation pits, check dams, rooftop-water harvesting, underground tanks, open area harvesting, and artificial recharging pits connected to drains in the urban areas.

\subsection{Introduction}

The possible pollutants in pond water are virtually limitless and can be classified as organic or inorganic (chemical), biological, physical, or radiological. Mankind, in order to meet the requirements of the growing population, is unwisely using these toxic substances and causing irreparable damage to the fragile ecosystem. Pollution is the most pervasive of all the effects of industries. All leading industries, such as petrochemicals, heavy chemical, agriculture (fertilizers, pesticides...) etc., have based their activities in the periphery of Baroda and have obviously created a dire drinking water problem for Vadodara city, as pond water status is affected by the waste of such industries. In this chapter, the effect of pollution on the pond water of Baroda city and industrial area is discussed. Baroda is situated in the center of the fertile mainland of Gujarat, and occupies a prominent position among the districts of the state, being one of the socially, economically, educationally and industrially advanced districts in the state. Baroda city is situated between Narmada and Mahi River and the bank of the Vishwamitri river. It is between $22^{\circ} 17^{\prime} 59$ North latitude and $73^{\circ} 15^{\prime} 18^{\prime \prime}$ East longitude. It is $108.22 \mathrm{k}^{2}$ in area. The city had a population of 1.6 million at the latest census (2001) and is the third largest city in the state. It ranks twenty-first among the cities of India. Generally in Gujarat rainfall is unpredictable. About $500-700 \mathrm{~mm}$ annual rainfall is received in the monsoon months (June to September). The highest maximum temperature is about $45^{\circ} \mathrm{C}$ and lowest minimum about $6^{\circ}$ to $7^{\circ}$. It has various types of soils i.e. deep black soils, besar, "goradu", alluvial sandy loam, undulating and hilly soils. 


\subsection{Materials and Methods}

To study the water contamination, samples were collected from different ponds shown in Figures 33.1-33.5, namely:

1. Sursagar pond,

2. Harani pond,

3. Sindhusagar pond,

4. Mohammad pond, and

5. Manjalpurpond.

Composite samples were collected during winter (October-January), summer (February-May); and monsoon (June-September). Samples were preserved and analysed according to the standard method (APHA-1995, Trivedi and Goal, 1986) and values presented as seasonal averages.

\subsection{Pond Water}

A water body can acquire colour from materials such as silt, clay, algae, decaying matter and salts. The Sursagar pond water was colourless in all three seasons. The Harani pond was turbid in monsoon and winter, and clear in summer. The Sindhusagar pond water colour indicated turbidity in monsoon and summer, while clear in winter. The Mohammad pond water was colourless in all three seasons. Manjalpur pond water was turbid in monsoon, and colourless in winter and summer. The colour of the pond water during monsoons is due to rain and turbulence, which causes turbidity due to sand, silt and clay particles (Unni, 1996).

All the pond water studied was odourless in all the seasons, except Sindhusagar pond. Odourless water indicates less biological activity and freedom from exogenous materials.

Suspended particles in water can be in the form of clay, silt, organic matter or plankton. Turbidity levels shown in Figure 33.6 can indicate the land use pattern in the catchment area and help in determining primary productivity levels of the water body (Kumar and Ravindranath, 1998). Turbidity of pond water was found to be between 20 and 65 NTU during monsoons. The water of all the ponds was highly turbid in all three seasons. This could be due to the location, being city areas with biotic and construction activity.

Higher turbidity is due to cattle (buffalo etc.) movement through the pond and human settlements around the ponds, which may be releasing some waste materials in the ponds. A bridge, passing across the pond, also increases biotic 


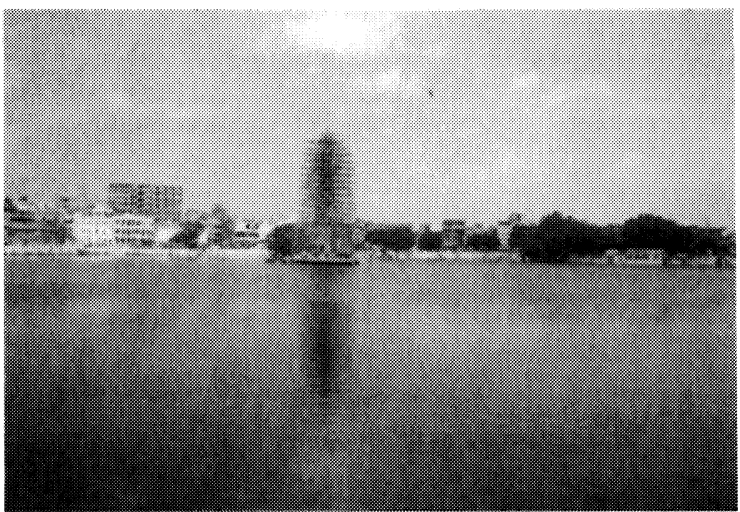

Figure 33.1 Sursagar pond.

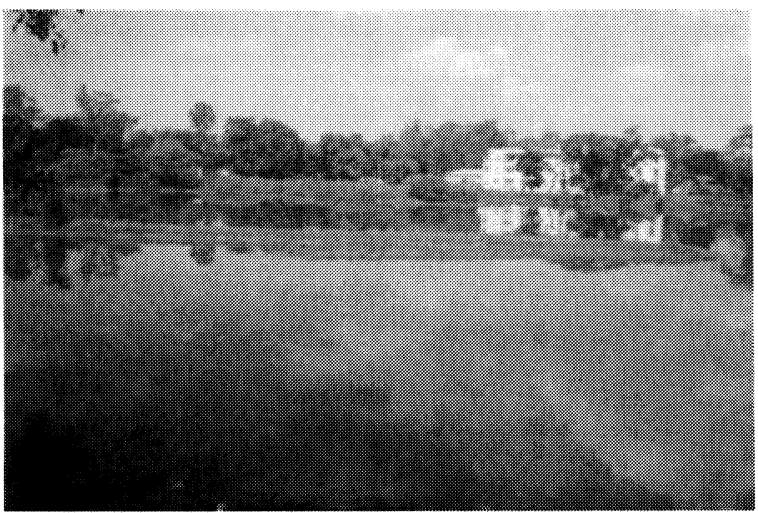

Figure 33.2 Harani pond.

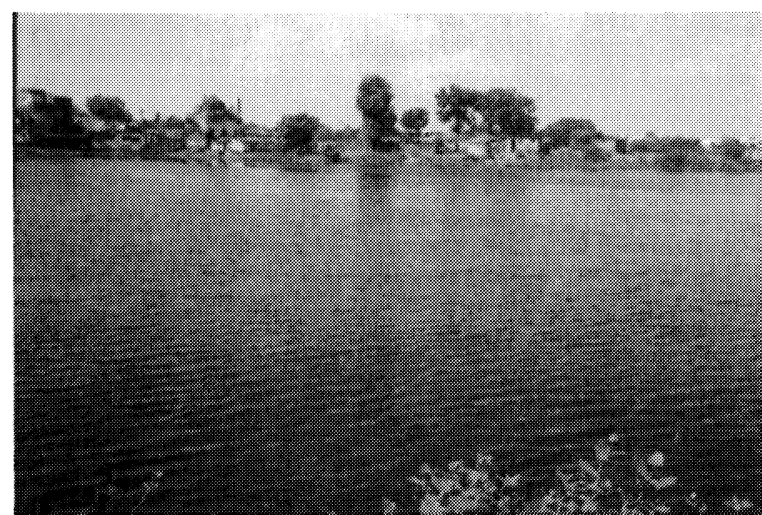

Figure 33.3 Sindhusagar pond. 


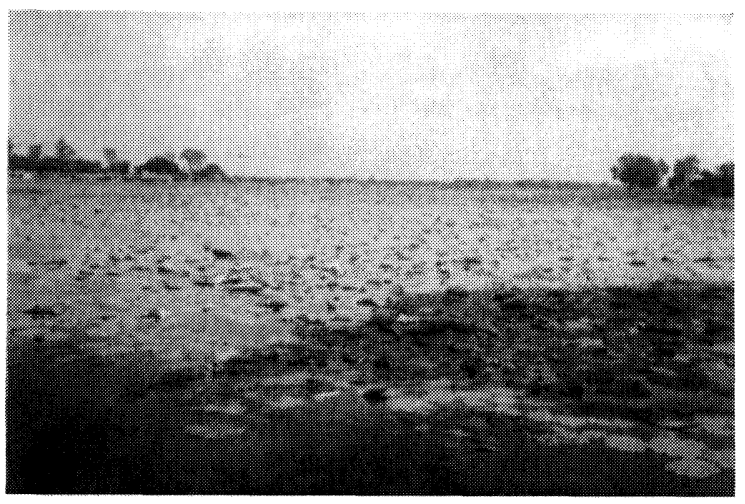

Figure 33.4 Mohammad pond.

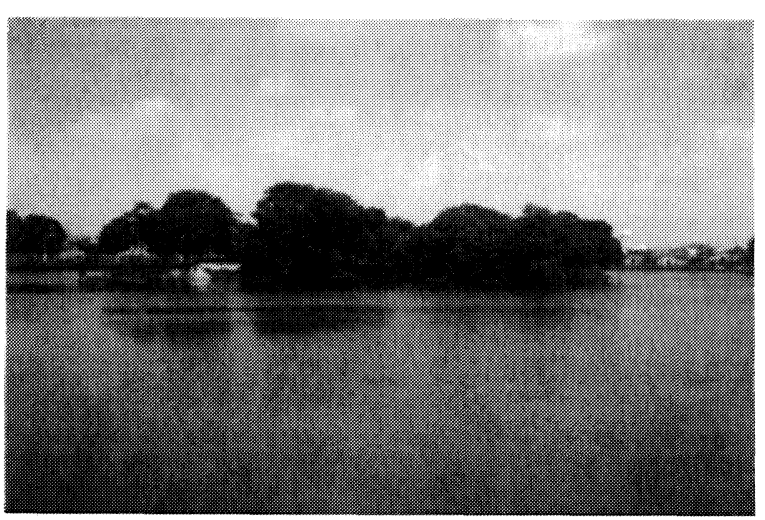

Figure 33.5 Manjalpur pond.

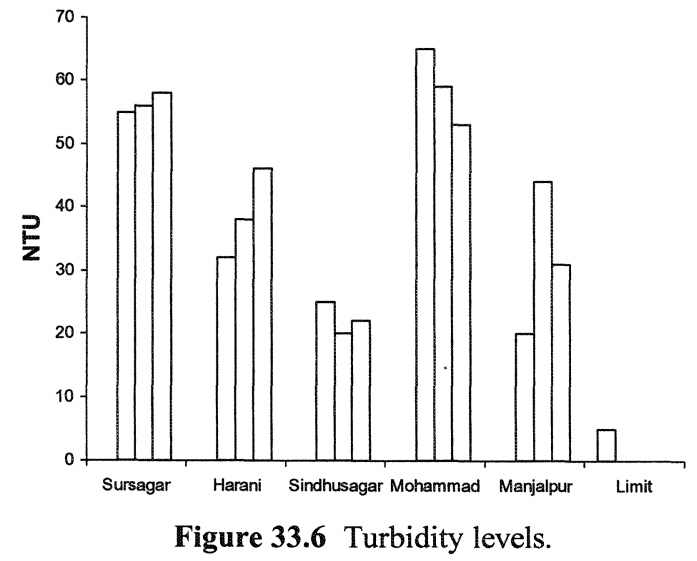


activity. Turbidity could also result from the geology of the pond itself, where some materials may be added through erosion.

In all the sampling sites, the electrical conductivity (EC) shown in Figure 33.7 showed the same trend: highest in monsoon and lowest in summer, and the values were quite comparable. In the monsoon, water is free of vegetation and aquatic life, therefore all ions are accumulated in the water, but once aquatic life develops, the ions are absorbed by the living organisms. This utilization of ion reduces EC values in winter and summer. After the decomposition of the plants and animals, all ions are released back into the water after summer (Vora et al., 1998 and Ahluwalia, 1999), and these raise the EC value in monsoon, as there were a few living organisms.

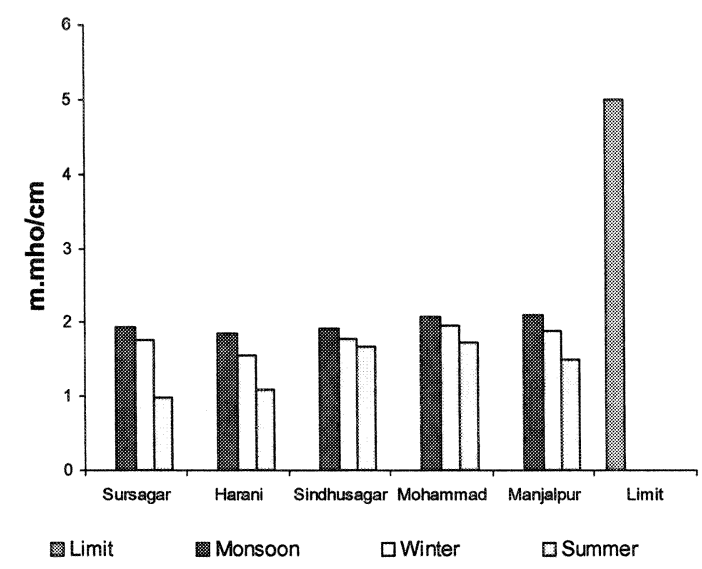

Figure 33.7 Electrical conductivity.

Dissolved solids shown in Figure 33.8 ranged between 1123 ppm (Manjalpur Pond) and $1896 \mathrm{ppm}$ (Sursagar Pond) in monsoon. In winter and summer it was low at $1210 \mathrm{ppm}$ (Manjalpur Pond), and high up to $2089 \mathrm{ppm}$ (Sursagar Pond). In other areas the values were intermediate. Dissolved solids (DS) were lower during monsoons because of rainwater dilution. As the pond water volume decreases and living organisms start growing and developing, there are also simultaneously decomposition processes through which salts are released and increase DS (Vora et al., 1998 and Ahluwalia, 1999).

The $\mathrm{pH}$ shown in Figure 33.9 of all the pond water did not show much variation with respect to seasons, ranging between 7.20 and 7.81. The water was alkaline in nature, which could be due to solutes, which may show a buffering action i.e. $\mathrm{H}^{+}$ions are compensated with $\mathrm{OH}^{1-}$ ions (Vora et al., 1998). 


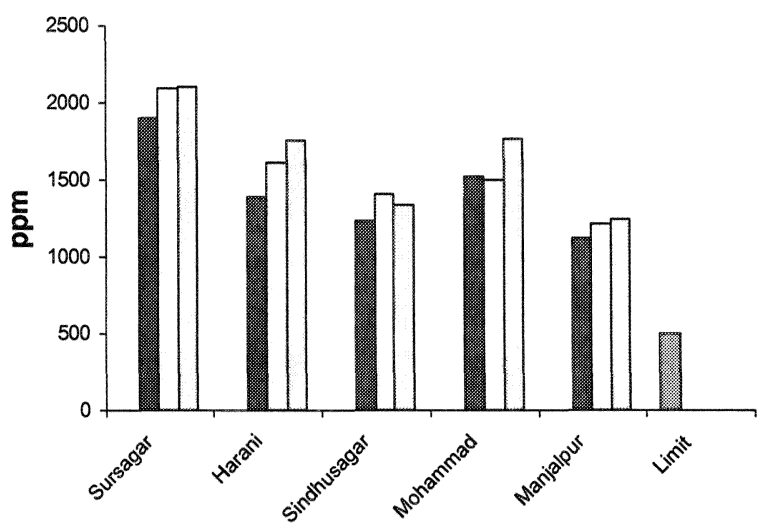

Figure 33.8 Dissolved solids.

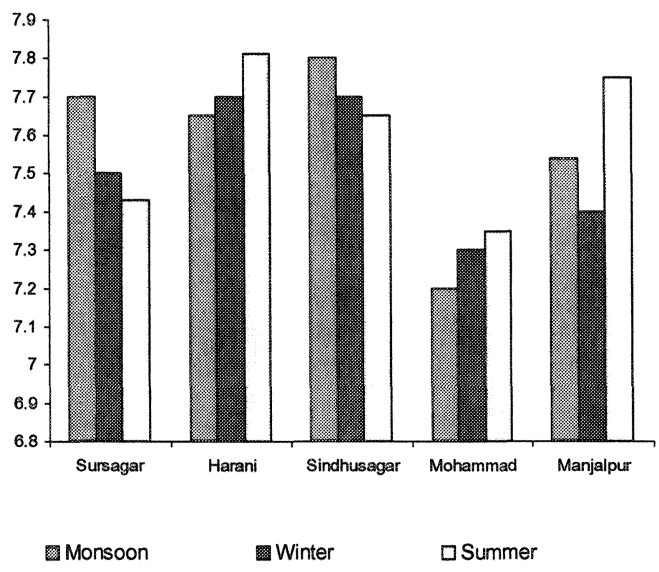

Figure $33.9 \mathrm{pH}$.

The alkalinity shown in Figure 33.10 is due to salts containing carbonates, bicarbonates, silicates and phosphates along with hydroxyl ions in a free state. It was seen that the alkalinity of all the pond water was lowest at $209 \mathrm{ppm}$ (Manjalpur pond) and highest at $578 \mathrm{ppm}$ (Sindhusagar pond) in all three seasons, while in the other areas the values are intermediate. Alkalinity was comparatively lower in Sursagar pond, Harani pond and Manjalpur pond, but in Shindhusagar pond and Mohammad pond it was quite high because they are used as "washing ghat", releasing alkaline chemicals such as caustic soda, etc. The changes in alkalinity depend on carbonate and bicarbonate; which in turn 


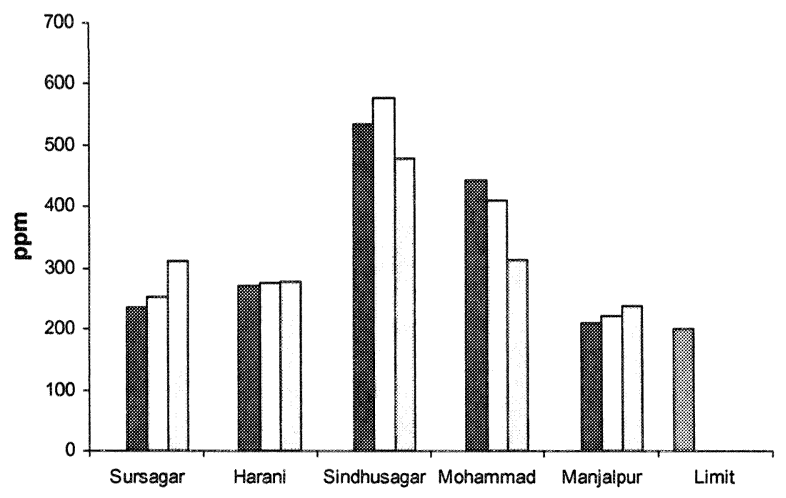

Figure 33.10 Alkalinity.

depend upon the release of $\mathrm{CO}_{2}$. Changes in carbonate and bicarbonate also depend upon the release of $\mathrm{CO}_{2}$ through respiration of living organisms. This is also used by the aquatic vegetation for photosynthetic activities. Bishogni (1973) observed that the total alkalinity declined during the monsoon season due to rainwater, leading to the dilution of the ion content of the water body.

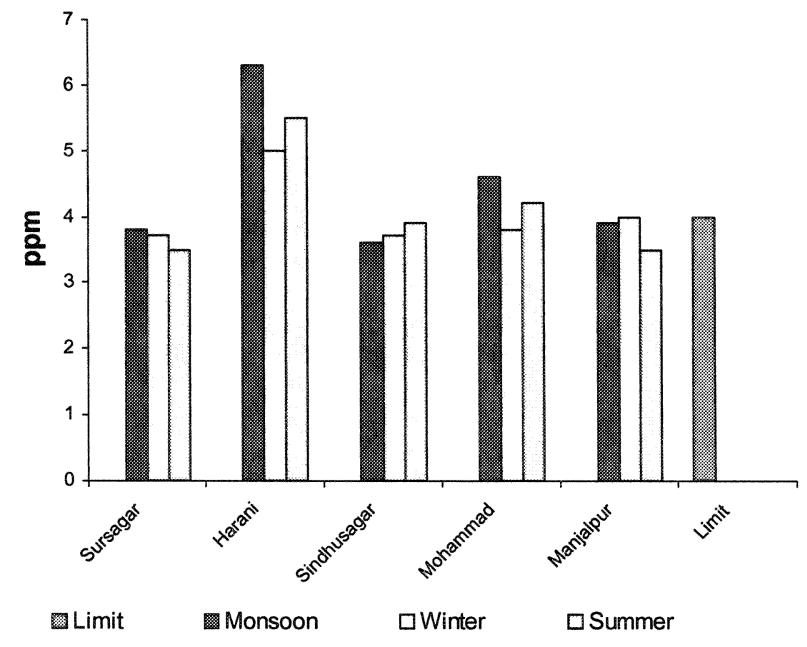

Figure 33.11 Dissolved oxygen.

Much of the dissolved oxygen shown in Figure 33.11 comes from the atmosphere due to wind (air) action. Algae and macrophytes aquatic plants also release oxygen through photosynthesis. The oxygen content varies with 
temperature, salinity, turbulence, respiration and photosynthetic activity of algae and higher plants and the atmospheric pressure. DO values were higher in those ponds where there was good aquatic life (Vijayan, 1991). Variations in the amount of DO can occur from time to time in a day. DO levels rise because of photosynthesis during morning hours. Late in the afternoon, DO levels are highest. Plants and animals continue to consume oxygen through respiration. Also oxygen is used for the decomposition of organic matter. This reduces the DO level (Kumar and Ravindranath, 1998). This kind of fluctuation in DO from late afternoon to early morning is characteristic of still waters.

BOD shown in Figure 33.12 increases with the amount of organic matter in water. If there are more anaerobic bacteria, BOD will increase. A large amount of organic matter in water results in a good growth of decomposer organisms. These demand a high amount of oxygen for their respiration,leading to DO deficiency and anaerobic conditions. The BOD test is important for assessing the pollution of water bodies due to organic wastes. The BOD data did not reflect any pollution in any of the ponds studied.

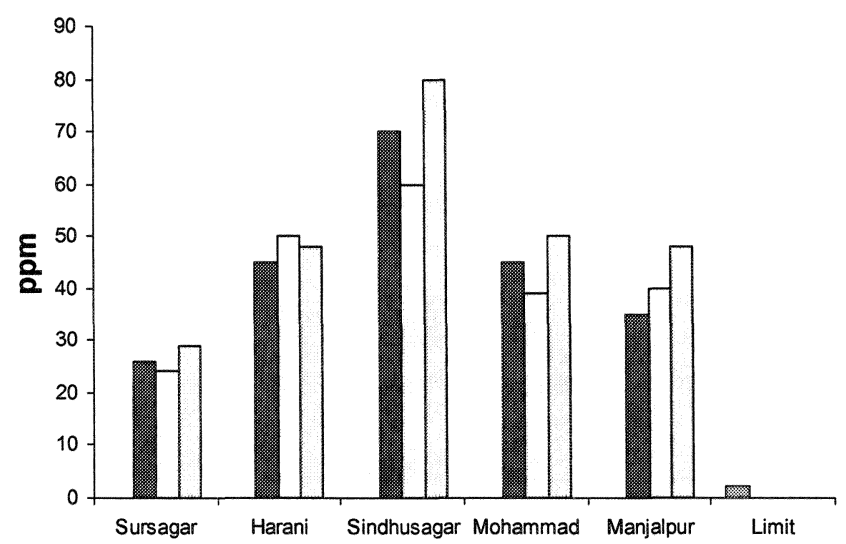

Figure 33.12 Biochemical oxygen demand (BOD).

COD (chemical oxygen demand) shown in Figure 33.13 is a measure of the total oxygen required to completely oxidize all the organic matter by a strong oxidant such as dichromate or permanganate. This includes biologically oxidisable and biologically inert organic matter. Therefore, COD values are usually higher than the BOD values (Kumar and Ravindranath, 1998). COD values were quite high because of many chemicals found in the water, both chemicals which are naturally occurring, and those which are released through the decomposition of dead organisms. Though the effluents of industries contain a considerable amount of organic matter, the BOD will be very little, as 


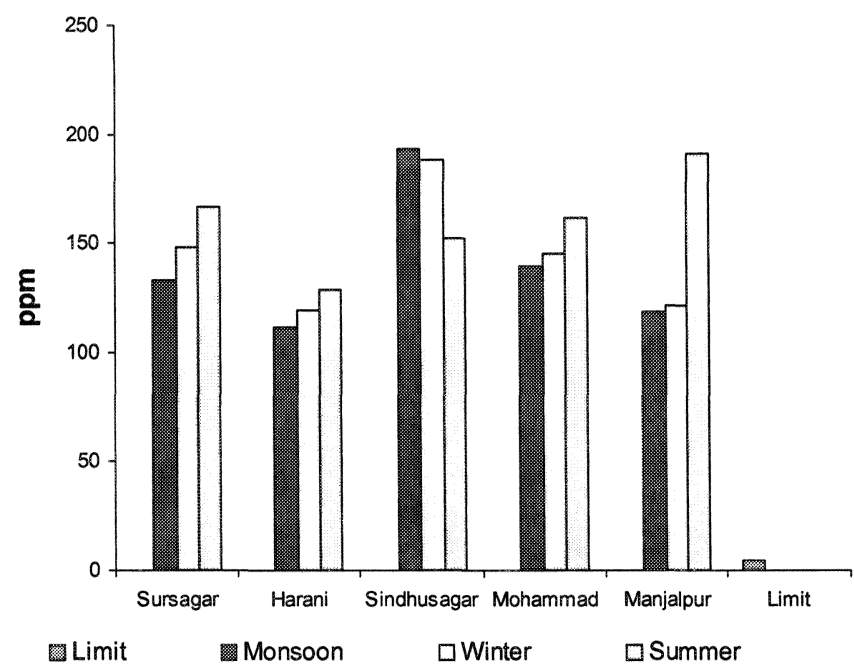

Figure 33.13 Chemical oxygen demand (COD).

the pollutants are not biodegradable, and this can lead to wrong conclusions regarding the quantity of organic matter present. In such cases COD can reveal the correct picture. The concentration of COD is usually less than 20 parts per million oxygen in unpolluted waters, and higher values may indicate pollution from domestic sewage and industrial effluents (Mitchell and Stapp, 1991).

As aquatic plants and animals die, bacteria break down large protein molecules into ammonia. Ammonia is further oxidized by bacteria to form nitrites $\left(\mathrm{NO}_{2}^{-}\right)$and nitrates $\left(\mathrm{NO}_{3}^{-}\right)$as shown in Figure 33.14. An excess of nitrates also causes eutrophication and increases BOD in turn (Kumar and Ravindranath, 1998). Nitrate was highest in monsoon and in summer in Sindhusagar pond, and high in Manjalpur pond, even then the values are quite low compared to ISI and WHO standards. In other words the ponds are not truly eutrophic as observed by Ahluwalia (1999) for Nal-Sarovar. The seasonwise variation in nitrate content reflects the status of $\mathrm{NO}_{3}$ in that particular pond. Thus for example the highest value of Shindhusagar pond in the monsoon could be due to decomposition of biota during the preceding seasons. The highest value in Manjalpur pond in winter could be due to nitrogen fixing organisms, while in summer the highest value could be due to both fixation and decomposition of biota. The nitrate and phosphate concentration of lake water were observed to be low. This may be either due to higher denitrifying bacterial activities at increased temperature or due to the utilization of nitrate and phosphate by the aquatic plants/biota (Verma and Mohanty, 1995). 


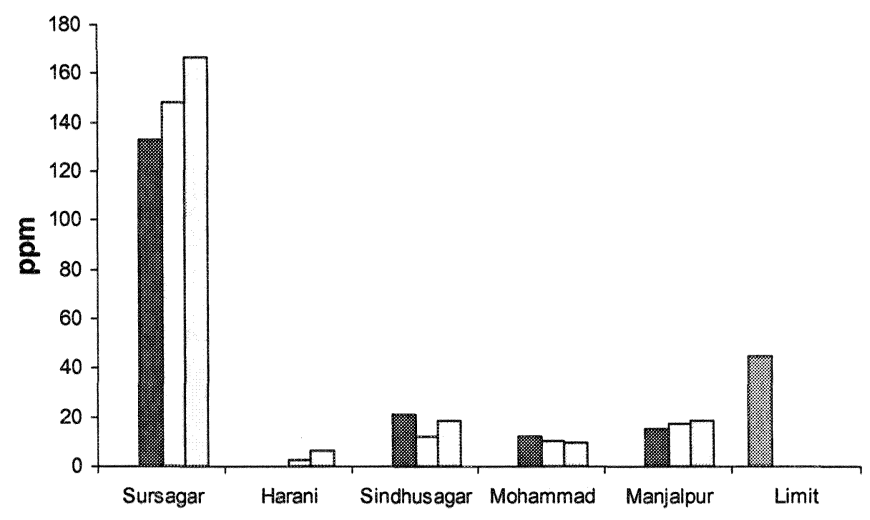

Figure 33.14 Nitrate(as- $\left.\mathrm{NO}_{3}\right)$.

Detergents in sewage, industrial effluents and fertilizer runoff contribute to increased levels of phosphates. Total phosphates in water include both organic and inorganic phosphates (orthophosphate and condensed phosphates). Organic phosphates are a part of living and dead plants and animals; over $85 \%$ of total phosphorus is usually found in organic forms. Inorganic phosphorus, in the form of orthophosphates, plays a major role in an aquatic system. If precipitated under oxidizing conditions and lost to the sediments, it results in the depletion of phosphorus in water. On the other hand, under reducing conditions, some phosphorus returns to the water in a soluble form (Saxena, 1990). $\mathrm{PO}_{4}$, as shown in Figure 33.15, was quite low in Sursagar pond; and in Sindhusagar pond, Mohammad pond and Manjalpur pond, where there are human activities, "Dhobi Ghat" (use of detergent) and other biological activities - $\mathrm{PO}_{4}$ was quite high. It may be noted here that the $\mathrm{PO}_{4}$ is within the permissible limits of WHO and ISI. Secondly, the slight fluctuation season-wise could be due to biotic activities both in uptake and release. The higher value of $\mathrm{NO}_{3}$ and $\mathrm{PO}_{4}$ does not signify any eutrophication.

Sulphates, shown in Figure 33.16, are found in natural water. Water containing a high concentration of sulphate (more than $250 \mathrm{ppm}$ ) has a laxative effect (in fact in earlier times $\mathrm{MgSO}_{4}$ known as Epsom salt was prescribed as a purgative medicine), which is enhanced when sulphate is consumed along with magnesium (Kumar and Ravindranath, 1998). $\mathrm{SO}_{4}$ (sulphate) values also fluctuated pond-wise and season-wise.

Chloride, shown in Figure 33.17, was generally highest in summer. It starts rising from monsoon to summer. Chloride $(\mathrm{Cl})$ content has been found to increase post-monsoon through winter to summer, being lowest in the 


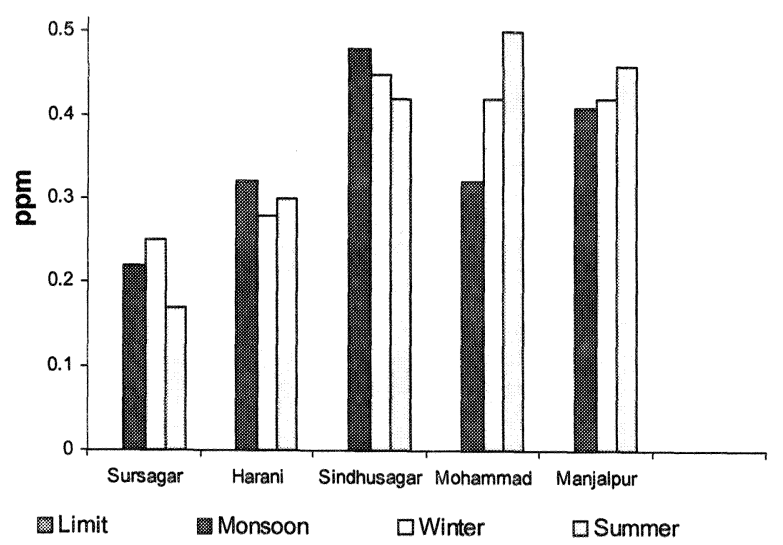

Figure 33.15 Phosphate (as- $\mathrm{PO}_{4}$ ).

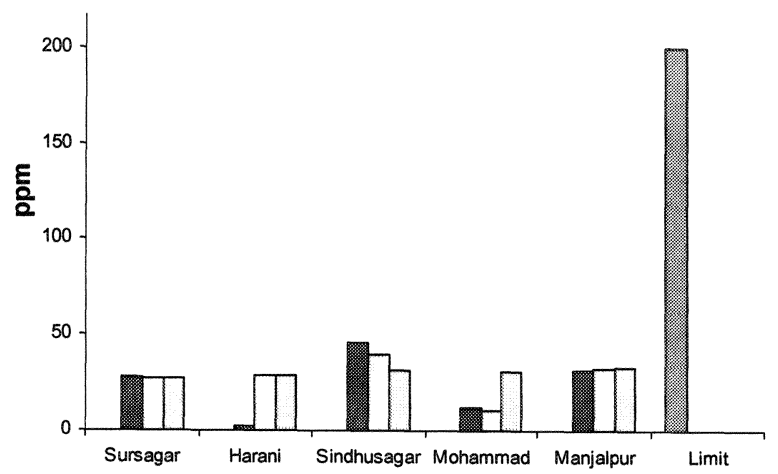

Figure 33.16 Sulphate (as- $\mathrm{SO}_{4}$ ).

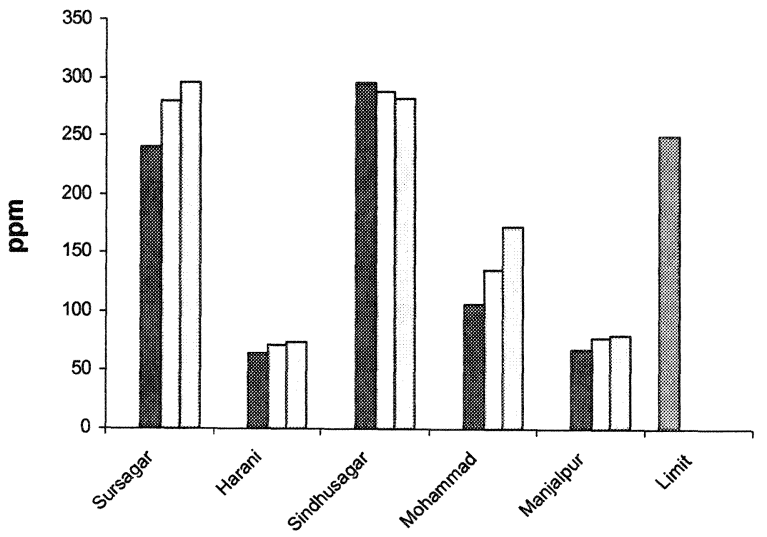

Figure 33.17 Chloride. 
post-monsoon and highest in summer in most of the ponds. The reason for this can be attributed to the soil at the bottom and climatic conditions prevailing in the area. Chlorides, being water-soluble, leach down on the accumulation of rainwater in the pond - hence the low values occurring during the monsoon and post-monsoon period. Once the monsoon is over a gradual shrinkage of the water body takes place, due to the evaporation, which accelerates with the rise of temperature. As a result, chloride concentration increases (Vora et al., 1998 and Ahluwalia, 1999).

Fluorides, shown in Figure 33.18, occur in water because of the weathering of fluoride- bearing granite rock, limestone, etc. and enter the surface waters from runoff and from groundwater (Kumar and Ravindranath, 1998). Effluents from fertilizer, glass manufacturing, and chemical manufacturing industries are the major contributors of fluorides to water. Fluoride was within the limits of WHO and ISI, except in Mohammad pond in winter, when it was quite high.

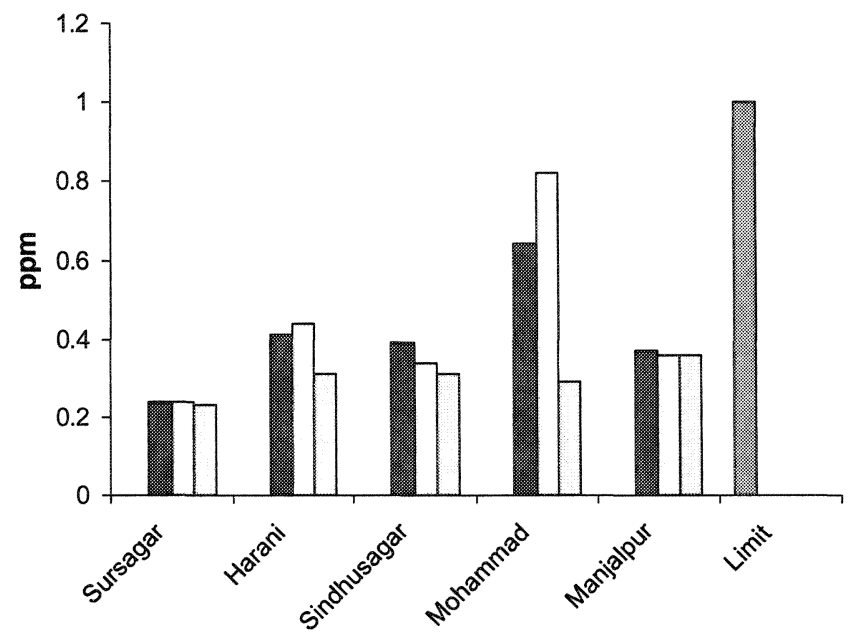

Figure 33.18 Fluoride levels.

The total hardness, shown in Figure 33.19, in monsoons was highest at $472 \mathrm{ppm}$ (Sindhusagar pond) and lowest at $160 \mathrm{ppm}$ (Mohammad pond). In winter it was highest at $461 \mathrm{ppm}$ (Sindhusagar pond) and lowest at $143 \mathrm{ppm}$ (Harani pond) while in summer it was highest at $491 \mathrm{ppm}$ (Sindhusagar pond) and lowest at $180 \mathrm{ppm}$ (Harani pond). In the other areas the values were intermediate. 


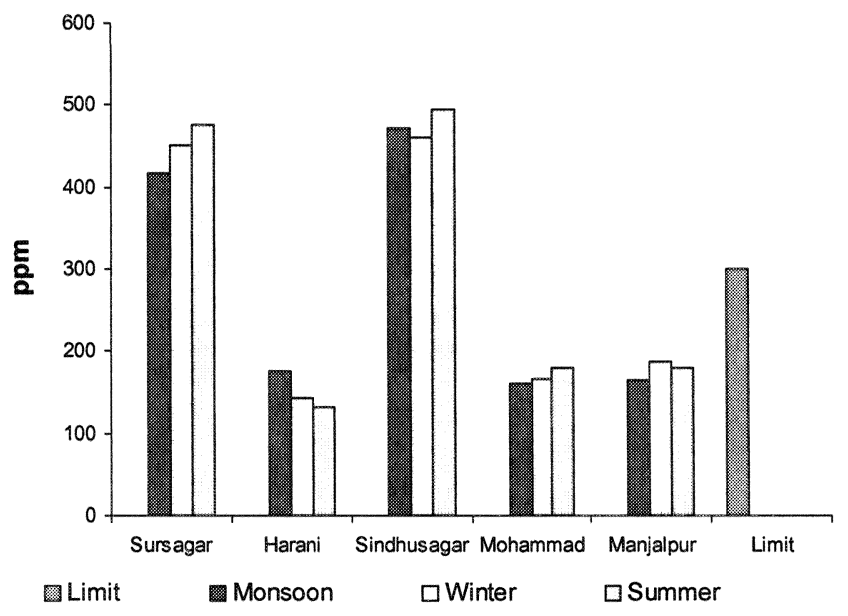

Figure 33.19 Total hardness.

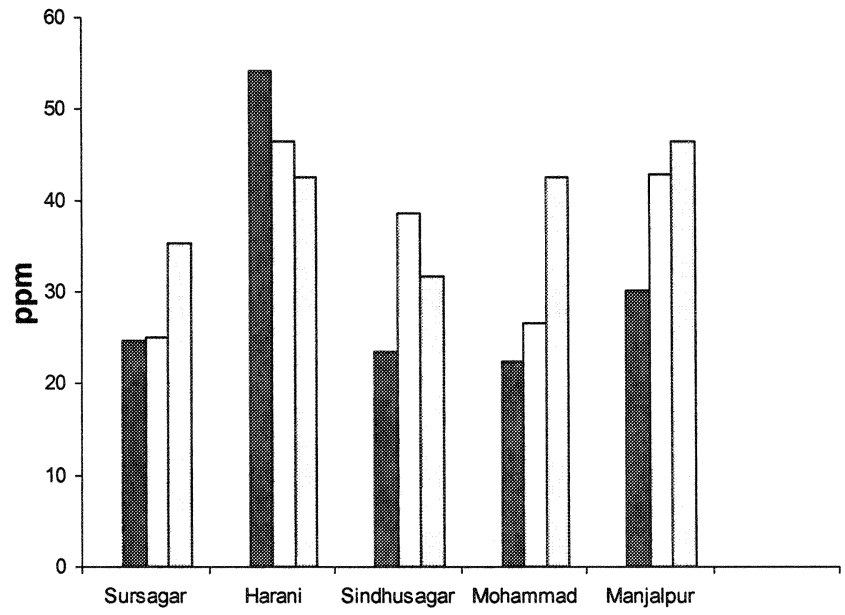

Figure 33.20 Sodium.

Hardness increased with the number of hot days, as the summer season approaches. Low hardness in winter may be because of the high volume of water as well as vegetation. A number of plants - macrophytes and algae use $\mathrm{CO}_{2}$ and hence $\mathrm{CO}_{3}$ amount reduces. Calcium and magnesium being used up / absorbed by living organisms, hardness is low when vegetation decomposes; they are released back into the substratum, thereby increasing hardness (Ahluwalia, 1999). 
The sodium content shown in Figure 33.20 showed variation season-wise and site-wise e.g. Sursager pond, Mohammad pond and Manjalpur pond showed a slight increase in summer from the preceding seasons; Harani pond showed a decreasing trend from monsoon to summer. In Sursagar pond, Mohammad pond and Manjalpur pond, sodium increased in summer, due to the shrinkage of water volume. In Harani pond and Sindhusagar pond the decrease in sodium content in winter to summer could be due to the uptake of sodium by living organisms to maintain and regulate osmosis.

Potassium $(\mathrm{K})$, is shown in Figure 33.21. Except in Harani pond there was no change observed season-wise and sampling-wise. However, it can be correlated with sodium content; specially, in the case of Harani pond, where sodium is in much higher quantities than potassium. It is known that living organisms take up potassium.

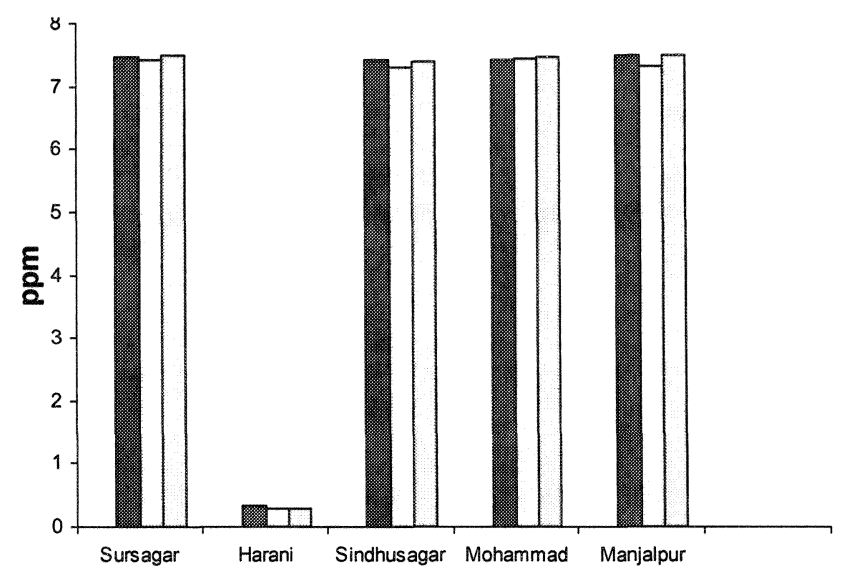

Figure 33.21 Potassium.

In all ponds, no oil and grease whatsoever were detected, showing a pollution free condition.

Arsenic (Ar) in drinking water below $0.05 \mathrm{mg} / 1$ is no health hazard (WHO, 1988). Lead $(\mathrm{Pb})$ in high concentration $(0.0$ to $0.2 \mathrm{mg} / 1)$ for long exposure can cause tiredness, lassitude, slight abdominal discomfort, irritability, anemia and behavioral changes in children (WHO, 1988). Drinking waters having $5 \mathrm{mg} / 1$ of chromium are toxic to animals (WHO, 1988). In this range it can be carcinogenic (Sahu, 1991). Drinking water having more than $0.1 \mathrm{mg} / 1$ of cadmium can cause bronchitis, emphysema, anemia and renal stone formation in animals (WHO, 1988). 
Heavy metals, shown in Figure 33.22, do not show values outside the permissible limit except in Harani pond. Cadmium (Cd) and Chromium $(\mathrm{Cr})$ show slightly higher values than the permissible limits, perhaps because of some nearby small-scale industries of processing nature, which might be releasing $\mathrm{Cr}$ and $\mathrm{Cd}$ in their effluents, or from the original rock sediments. The slight content of $\mathrm{Cr}$ and $\mathrm{Cd}$ in Manjalpur pond was due to its original earthly occurrence.

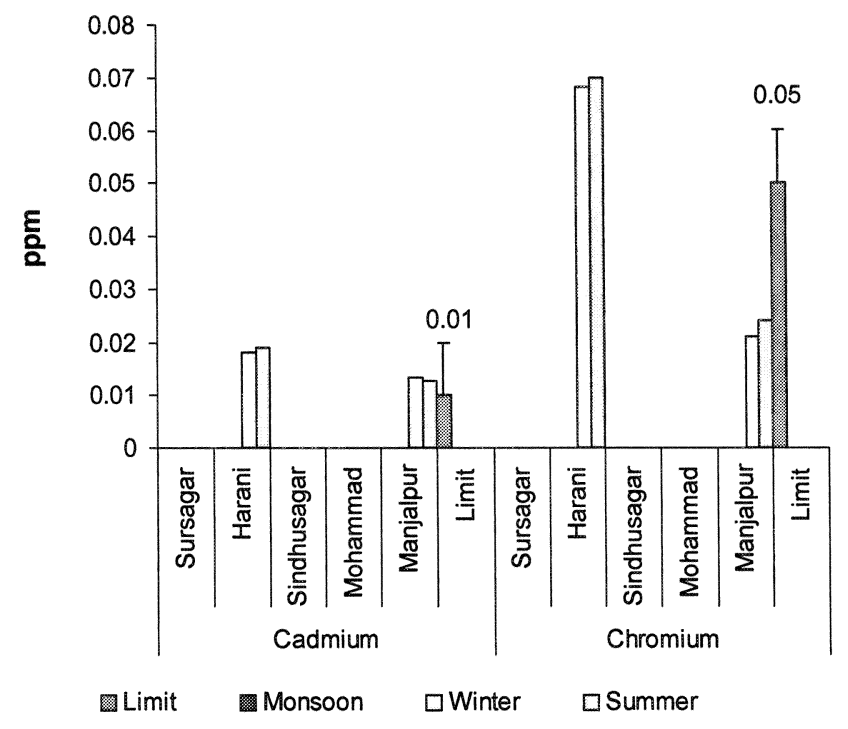

Figure 33.22 Metals.

The correlation among physico-chemical parameters of pond water was examined.In general, positive correlation of $\mathrm{pH}$ was observed with $\mathrm{NO}_{3}, \mathrm{PO}_{4}$, $\mathrm{SO}_{4}, \mathrm{Cl}, \mathrm{TH}, \mathrm{Ca}, \mathrm{Mg}, \mathrm{Na}, \mathrm{Cd}$ and Cr. Verma and Mohanty, (1995); Ali et al. (1983) and Freiser and Feranando (1966) observed similar positive correlations. Mohanty (1981) had also observed negative correlations of $\mathrm{pH}$ with $\mathrm{Ca}$ in Bhubaneswar water bodies, while positive correlation in monsoon and summer could be due to more carbonate formation by elements reacting with bicarbonate; it is difficult to say anything definite about the negative correlations. Negative correlations of $\mathrm{pH}$ with $\mathrm{Ca}$ was probably due to loss of some $\mathrm{Ca}^{2+}$ in the sediments in form of precipitate, resulting in low $\mathrm{Ca}^{2+}$ content (Atkin and Harris, 1924). Negative correlations of fluoride (F) with Ca was also observed by Das et al., (1999); Gupta et al., (1986); Das (1985); and Handa (1975). 
Positive correlations were found between total hardness and each of $\mathrm{Cl}$, $\mathrm{F}, \mathrm{EC}, \mathrm{Ca}, \mathrm{Na}$ and $\mathrm{K}$. The positive correlation between sodium and chloride is indicative of the presence of sodium chloride in this water. Total hardness with $\mathrm{Ca}, \mathrm{Mg}, \mathrm{NO}_{3}$ and $\mathrm{Cl}$ indicates that hardness in the pond water is mainly due to chloride and nitrate salts of calcium and magnesium. A good relation between alkalinity and sodium indicates that alkalinity in the region is mainly due to the presence of sodium bicarbonate. Almost similar trends were observed in all the three seasons.

Because of biotic activities in ponds, such as the decomposition of living organisms after death, all values were higher compared to the control . The ponds also absorb elements like calcium, magnesium, and potassium etc.

\subsection{Recharging Ground Water}

The largest source of water in arid and semiarid regions is rainfall and surface runoff in the area. The runoff water is heavily turbid due to sediments. The second one is treated effluents and sewage effluents, which may be allowed to percolate through the soil layers. The third one is by inter-connecting perennial rivers with seasonal rivers through canals and storing the water through dams or check dams in seasonal rivers.

It is necessary to map the land topography by conducting a survey and preparing a contour map. A contour map indicates the direction of the run-off water flow in the field. This also helps in locating the site for building percolation tanks, preparing contour bunds and dividing the field into small plots.

\subsubsection{Contour Bunds}

Bunds run along the same elevation, across the slope. Bunds can be long or short, depending on the slope of the field. If the bunds are short, they may be called staggered bunds.

Under this system, rainwater flowing from a higher elevation will accumulate in the trench. Silt, eroding from the top, will also be deposited in the trenches. Once the trenches are filled, the surplus water will flow from both sides of the staggered trench without causing any damage. This water is then collected in the next trench, located alternatively below the top row trenches.

In the case of long continuous bunds, surplus water has to flow over the bund, which often causes soil erosion. The damage to contour bund may increase further, if a proper level is not maintained along it during construction. 
Contour bunding will help in retaining maximum rainwater within the field. In addition to these bunds, percolation tanks and farm ponds can also be created to store the rain water.

\subsubsection{Gully Plugging}

The ideal method of water resources development is to build check bunds on nalhas and gullies to store run-off water within the field. Normally, about $20-30 \%$ of the rainwater percolates into the soil and the remaining water runs off, eroding fertile soils as well.

By developing contour bunds and opening furrows across the slope, the rate of rainwater percolation can be easily doubled. The drained water can be restored at the lower portion of the fields by building tanks or digging farm ponds. It is difficult to store water for a long time through such gully plugging, but it helps in recharging the groundwater and supporting form pond or percolating tanks dug at lower elevations.

\subsubsection{Percolation Tanks}

Percolation tanks are generally built by erecting a bund across a nalha or a main gully where water storage capacity is high, and water is retained for a longer period. In low rainfall areas, earthen bunds can be built and the earthen surface of this bund can be pitched with grasses and stones. A spillway should be provided adjacent to the bund to release surplus water from the tank. The level of the spillway should be sufficiently lower (about $1 \mathrm{~m}$ ) than the height of the earthen bund to prevent the flow of surplus water over the bund, and to avoid breaching.

\subsubsection{Other Water Sources}

In addition to harvesting of rain water, the digging of open wells or drilling of bore-wells can also be considered. It is essential to carry out a groundwater survey for identifying the sites before drilling bore wells.

\subsubsection{Water Distribution}

Lift irrigation schemes can pump water even from a distance of 8-10 km. Water stored in a tank can be pumped and irrigated directly by the furrow method. This method requires more water. If the water supply is limited, it is better to use drip or sprinkler methods. 


\subsubsection{Roof-top Harvesting}

In cities and towns, the multi-storied commercial and residential complexes can capture rainwater on the rooftop as shown in Figure 33.23. This collected water can be stored in an underground tank or drained directly into the bore well. In small houses and bungalows the roof-top water can be stored in an underground tank of the house. This underground storage tank technique is an old one in many towns and cities of Gujarat. Most municipalities have made it compulsory to construct underground storage tanks or direct connections with bore walls. Urban residents have made a permanent practice of capturing rain water through roof-top harvesting. It has been observed that 10,000 to 12,000 liters of water collected during the rainy season per year is enough for a family of 4 to 5 persons.

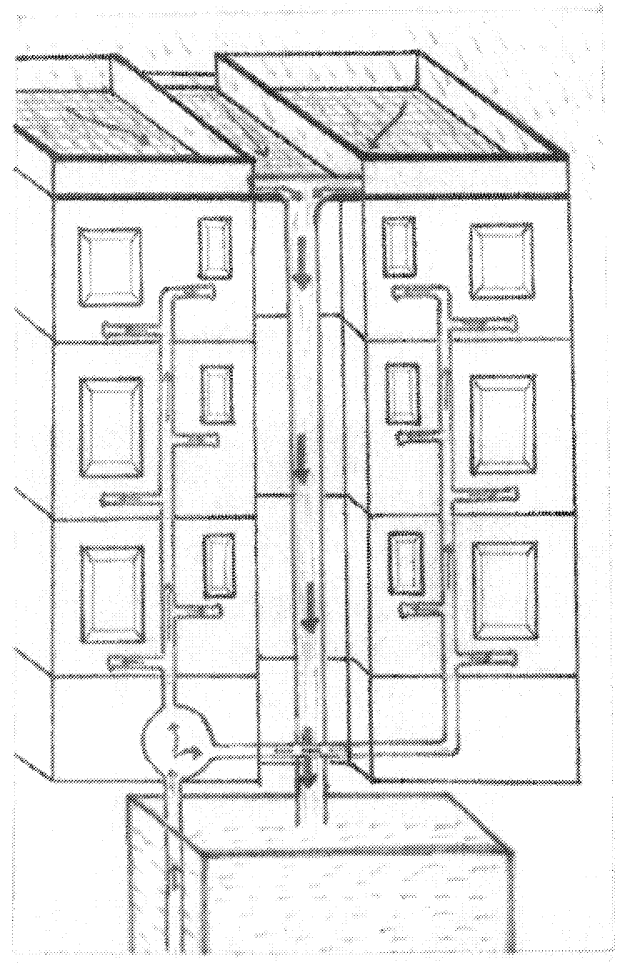

Figure 33.24 Rooftop harvesting. 
Rainwater harvesting and recharging water systems appear to have a very significant role in Gujarat state. Every raindrop has its own value in the droughtprone area. It is said "Catch rainwater and there is a hope in the new millennium". Finally this is our "harvest of hope".

\section{References}

Ahluwalia, A. A. 1999.Limnological Study of wetlands under Sardar Sarovar command area. Ph. D. Thesis. Gujarat University, Ahmedabad.

Ali, A., Reddy, K.R. and De Busk, W.K. 1983. Seasonal changesin sediment and water chemistry of a subtropical shallow eutrophic lake. Hydrobiologia $159: 159-167$.

American Public Health Association, (APHA), (1995). Standard Method for the Examination of Water and Wastewater, 19th Ed. New York.

Atkin, W. R. G. and Harris, G.T. 1924. Seasonal changes in water and Heleoplankton of fresh water ponds. Sc. Proc. Roly. Dab. Soc.. XVIII (N.S) :1 - 21.

Das, D. K. 1985. Incidence of high fluoride in deep ground water in Betawa Basin, M.P., Central India. G.S.I. Rec. 116: 23 - 30.

Das, S., Mehata, B. C., Das, P.K., Shrivastava, S.K. and Samanta, S.K. 1999. Sources of high fluoride in ground water around Anugul, Dhenkenal district, Orissa. Poll. Res. $18(1): 21$ - 28.

Freiser, H. and Fernando, Q. 1966. Ionic equilibria in analytical chemistry, Willey and sons. New York.

Gupta, A. K. and Mehrotra, R. S. 1986. Studies of seasonal variations in $\mathrm{pH}$ and dissolved oxygen content in Sanhit Sarovar, Kurukshtra, Geo. Bios., 13(6): 273278.

Handa, B. K. 1978. Occurrence of heavy metals and cyanides in groundwater from shallow aquifers in Ludhiyana. I AWPC Tech. 5: $109-115$.

Kumar, S. M. and Ravindranath, S., 1998. "Water Studies - Methods for monitoring water quality". Published by Center for Environment Education (CEE), Bangalore, Karnataka, India: 191.

Mitchell, M. K. and Stapp, W.B. 1991. Field manual for water quality manual monitoring, Global River Environment Education Network, Michigan.

Mohanty, R. C. 1981. Water quality studies of some water bodies of Bhubneswar. Ph. D thesis Utkal University ,pp. 240.

Sahu, B. K. 1991. A study of the aquatic pollution load in the river Baramati. Ph.D thesis Sambalpur University, Sambalpur.

Saxena, M. M. 1990. Environmental Analysis: water, Soil and Air.Agro Botanical Publisheres (India).

Trivedy, R. K. and Goel, P. K.1986. In: Chemical and Biological Methods for Water Pollution Studies. 21.

Unni, K. S. 1996. Ecology of river Narmada, A.P.H. Publishing Corporation, New 
Delhi.

Verma, J. P. and Mohanty, R. G.1995. Physico-chemical characteristics of fresh water Malyanta pond at Laxmisagar. Poll. Res. 14 (2) : 259 - 263.

Vijayan, V. S. 1991. Keoladeo National Park Ecology Study. Final report (1980 -1990) BNHS, Bombay.

Vora, A. B., Ahluwalia, A. A., Gupte, R. Y. 1998. Study on water and soil, vegetation, zooplanktona and zoo-benthos. In: Environmental Impact Assessment of Sardar Sarovar Project on Nalsarovar Bird Sanctuary, Gujarat Ecological Education and Research (GEER) Foundation, Gandhinagar.

WHO, 1988. Guide lines for drinking water quality. Vol-2, WHO, Geneva. 